\title{
Factors influencing individual tree crowns detection based on airborne laser scanning data
}

\author{
Krzysztof Stereńczak \\ Forest Research Institute, Department of Computer Science and Modelling, \\ Sękocin Stary, ul. Braci Leśnej nr 3, 05-090 Raszyn, Poland. \\ Tel. +48 227150 325, fax: +48 227200 397, e-mail: K.Sterenczak@ibles.waw.pl
}

\begin{abstract}
Airborne laser scanning (ALS) technology allows accurate information about the forest environment to be obtained. The high precision of ALS allows the detection of individual trees. An individual tree is composed of many elements and requires relatively complex algorithms. Factors that determine and affect the accuracy of calculating the number of trees can be split into the following groups: biological factors, technical factors related to the flight and data acquisition parameters, technical factors related to data processing, problems of results verification.

The article synthesises the main problems arising during the development of methods for detection of individual trees and acquisition of their characteristics in a managed forest in Central Europe.
\end{abstract}

Key words: segmentation, tree detection, crown height model, accuracy

\section{Introduction}

For several years, airborne laser scanning (ALS) remains one of the most effective tools to obtain accurate data on area (Baltsavias et al. 1999). Research on applying ALS to analyses of the forest environment has been conducted since 1970s (Soloduchin et al. 1977; Nelson et al. 1984). Since the 1990s, several papers have described an exploitation of ALS to determine the parameters of the forest stand on the basis of digital terrain models and a point cloud (Clark et al. 2004; Weinacker et al. 2004; St-Onge et al. 2005; Hyyppä et al. 2006).

Information about the number of trees on an area is one of the most important data obtained using ALS. This parameter can be expressed as a density index. A set of points or a polygon can be one of the ALS data processing results. Points usually represent the highest parts of the canopy where the treetops are. Points can result from the crown height model (CHM) or the ALS point cloud analysis.

Received 17 April 2013, accepted after revision 15 July 2013. (C) 2013, Forest Research Institute
Polygons, obtained from the CHM or the ALS point cloud, describe the horizontal crown extent. Hence, they provide more useful and detailed information from the forest management point of view (Fig. 1).

The accuracy of determining trees number and the accuracy of the crown extent are important for determining the volume stock based on single trees (Korpela et al. 2007; Kaartinen, Hyyppä 2008; Miścicki, Stereńczak 2012). Many algorithms that can be used to determine the number of trees have been described in the literature (Hyyppä J. et al. 2001; Maltamo et al. 2004b; Tiede et al. 2005; Koch et al. 2006; Stereńczak et al. 2008; Tompalski et al. 2009; Myszkowski et al. 2009; Stereńczak 2010a; Wężyk et al. 2010). These algorithms give different results depending on forest stand composition and the system of forest management. Comparison of the accuracy of these algorithms (Kaartinen, Hyyppä 2008; Vauhkonen et al. 2010) proved that they are most accurate for forest stands for which they were developed. It is due to the fact that variables were 


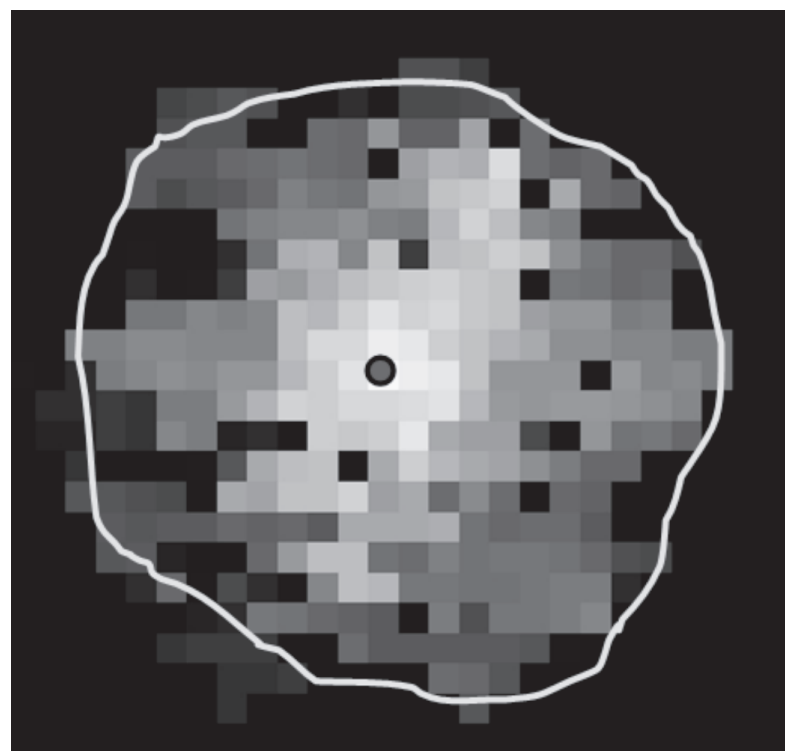

Figure 1. Result of a single tree detection based on canopy height model (dark point - position of pixel with the highest height value (equated as tree top), white line - crown extend

matched to environmental conditions of the individual locations.

There are many factors that affect the segmentation accuracy. Segmentation in the digital image analysis is a process that divides an image into segments (areas that group more than 1 pixel), which are homogenous regarding the selected features. Some features depend on the attributes of the analysed forest stand, some others depend on the specificity of the data used in an analysis, whereas other features depend on the way the ALS data are processed. The most important factors can be:

1. Biological factors:

a) tree species,

b) species composition and spatial distribution of trees,

c) vertical forest stand structure,

d) volume,

e) stand origin,

f) ecotype of the individual species,

g) a damage of assimilation apparatus and

h) forest stand age.

2. Technical factors related to the flight and data acquisition parameters:

a) height of the flight over the area,

b) size of the laser spot on the object,

c) maximum deviation angle of the laser beam (nadir-off), d) number of ALS points per area, and

e) type of scanner-impulse (discrete) or continuous wave system.

3. Technical factors related to data processing:

a) algorithm used to generate digital surface model (DSM),

b) resolution of digital terrain model (DTM), DSM, and the CHM,

c) data filtering, and

d) algorithm used to define crown extent.

4. Problems of results verification:

a) types of reference data used for verification and

b) type of verification of results (point-to-point, polygon-to-polygon).

The aim of this article is to describe and characterise the most important factors that affect the accuracy of determining the number of trees and their features on the basis of the ALS point cloud. The present work summarises the experiences gained during several research projects and analysis of several research areas.

\section{Biological factors determining segmentation accuracy}

Biological factors pertain to analysed forest stand and trees features. Forest stand structure, composition, age and a way of mixing trees of different species are the most important forest stand features, which determine segmentation accuracy and delineate the features of individual trees. The ALS point cloud analysis, representing one-layer forest stand, is easier to conduct than the analysis of a point cloud representing multilayer, selection forest stands. Since forest stands of homogenous composition and age create same dimensional pattern, it is easier to automate the detection process (Fig. 2).

Selected forest stands are characterised by variable shapes and sizes of the crown as well as by complex vertical stand structure. Small trees in the image are often overshadowed with the taller trees growing nearby. It is due to the fact that at registering the reflected signal, smaller trees are covered by the taller ones. When using a point cloud obtained with ALS, second-layer tree detection is possible only in specific conditions. When using the CHM, however, such analysis is impossible because the model reflects only the highest layer of crowns. Objects that are placed under the canopy of the first layer are not included in the surface interpolated 

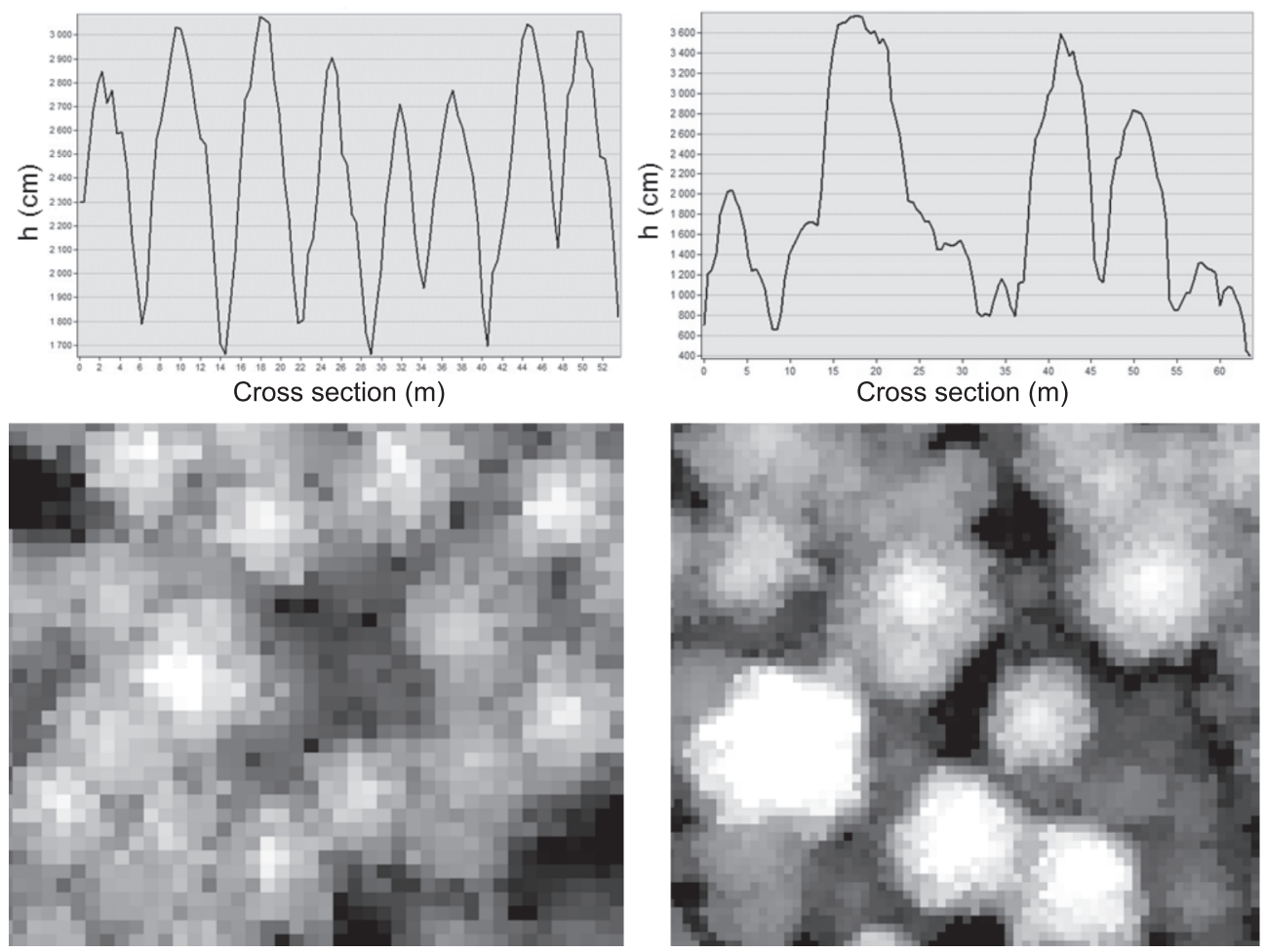

Figure 2. Comparison of vertical structure (cross section above) and horizontal structure (images below) of two tree stands: on the left - simple structure , on the right - complex structure; the bright pixels represent the greatest tree height values $H(\mathrm{~m})$

from the first echo point cloud. The problem is not significant, however, under the assumption that the aim of the analysis is to determine the stand volume on the basis of collected data. The accuracy of stand volume assessment is still very high, despite the fact that the second layer of forest stand is not included in the analysis (Persson et al. 2002; Hyyppä et al. 2005). Almost all volumes of large timber are placed in the first layer in both: coniferous and deciduous forest stands (trees of one generation). Hence, determining the appropriate number of trees in the highest layer of the forest stand is crucial for the determination of stand volume by the use of single-tree detection algorithms.

Tree species is yet another analysed factor. Results, presented in the literature, have pointed at higher accuracy of tree detection methods in coniferous forest stands than in deciduous ones (Persson et al. 2002, 2003; Heurich, Weinacker 2004; Tiede et al. 2004). It results from the characteristic forms of single-species crowns and dimension patterns that trees form (Fig. 3).

Since the beginning of growth, coniferous trees form conical crowns (less pine, more spruce, fir and larch).
The tree crown usually has one treetop that dominates over the side branches. Moreover, the deciduous species usually produce crowns more expanded and build of many dominant branches. They also tightly fill the space between trees. In effect, homogeneous exterior area of the CHM in crown higher layer is formed. In particular, it applies to beech, maple, ash and oak. Unlike these species, alder stands and birch stands do not grow so densely and their crowns do not form such varied shapes. They are rather homogenous, with one dominating top over adventitious branches. This, in turn, renders conducting the $\mathrm{CHM}$ analysis easier. The same problem occurs with regard to mixed-species stands. Analysis accuracy is lower because of adverse influence of deciduous species (Stereńczak 2013). This adverse influence results from reciprocal penetration of crowns of varied form and size, as well as from problems of appropriate algorithm settings.

Stand density is another factor that affects tree detection accuracy. Several results indicate that there is higher efficiency of tree detection methods in forest stands of lower density (Hyyppä et al. 2005). This is due to the fact that trees growing in higher density 

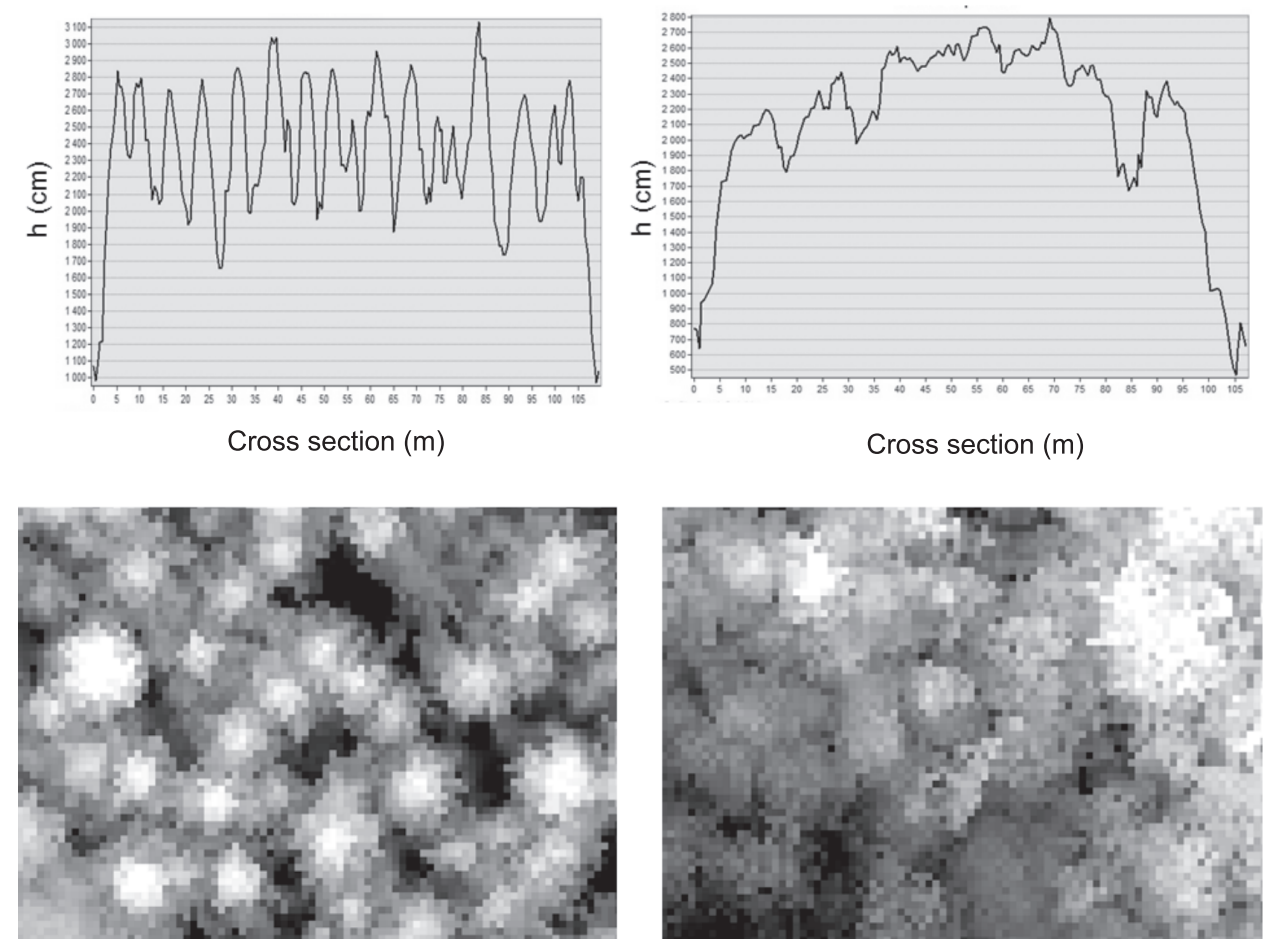

Figure 3. Comparison of vertical structure (cross section above) and horizontal structure (images below) of coniferous - on the left, and deciduous stands - on the right; the bright pixels represent the greatest tree height values $(H)$

form homogenous crown layers that interlace with each other. Forest management and silviculture result in regular coverage of the area and plain space between trees. Due to a larger space between individual tree crowns, laser beam penetration is higher and tree crowns are better represented by the CHM (Fig. 4). Segmentation results obtained in tree plantations are significantly better when compared with the results obtained in forest stands. Stand origin and the way of forest regeneration indirectly influence the tree detection results.

The accuracy of single tree detection based on ALS data depends on the knowledge about the ecotype. Significant differences in crown shapes can be observed in spruce stands. The weeping form of spruce produces crowns with downward shoots or with geotropism features (Picea abies 'Inversa'). The hanging form (Picea abies 'Pendula') creates thin, arch wise, hanging down branches. The cone form (Picea abies 'Piramidata') produces crowns of outstretched cone shape. High variability of crown shapes creates difficulties in delineating optimal algorithm parameter setting and lowers the accuracy of the application.
Occurrence of trees' individuals characterised by a foliage growth high variability (spring) and loosing leafs in autumn is another factor that influences the accuracy of the tree number determination (Będkowski, Stereńczak 2012, 2013). Oak is an excellent example of this phenomenon. For this species, the duration of the foliage growth in the spring between trees in the same stand can be up to a dozen days. The same differences are observed at the end of the growing season. This factor - in case of incorrect time of flight - can cause problems with finding trees already/yet in the leafless phase.

The damage of the assimilatory apparatus caused by biological factors (fungi and insects) is another factor. Primeval pest is a typical example. It damages leafs and young stems on the tree. It can sometime even cause changes in crown shape. Although damages caused by the pest are rare, they can complicate the procedure of tree detection even further.

Stand age is the last factor that can influence the accuracy of determining tree number. The younger a tree, the smaller crown it has. If all age classes of one tree species were reflected in one raster model of 


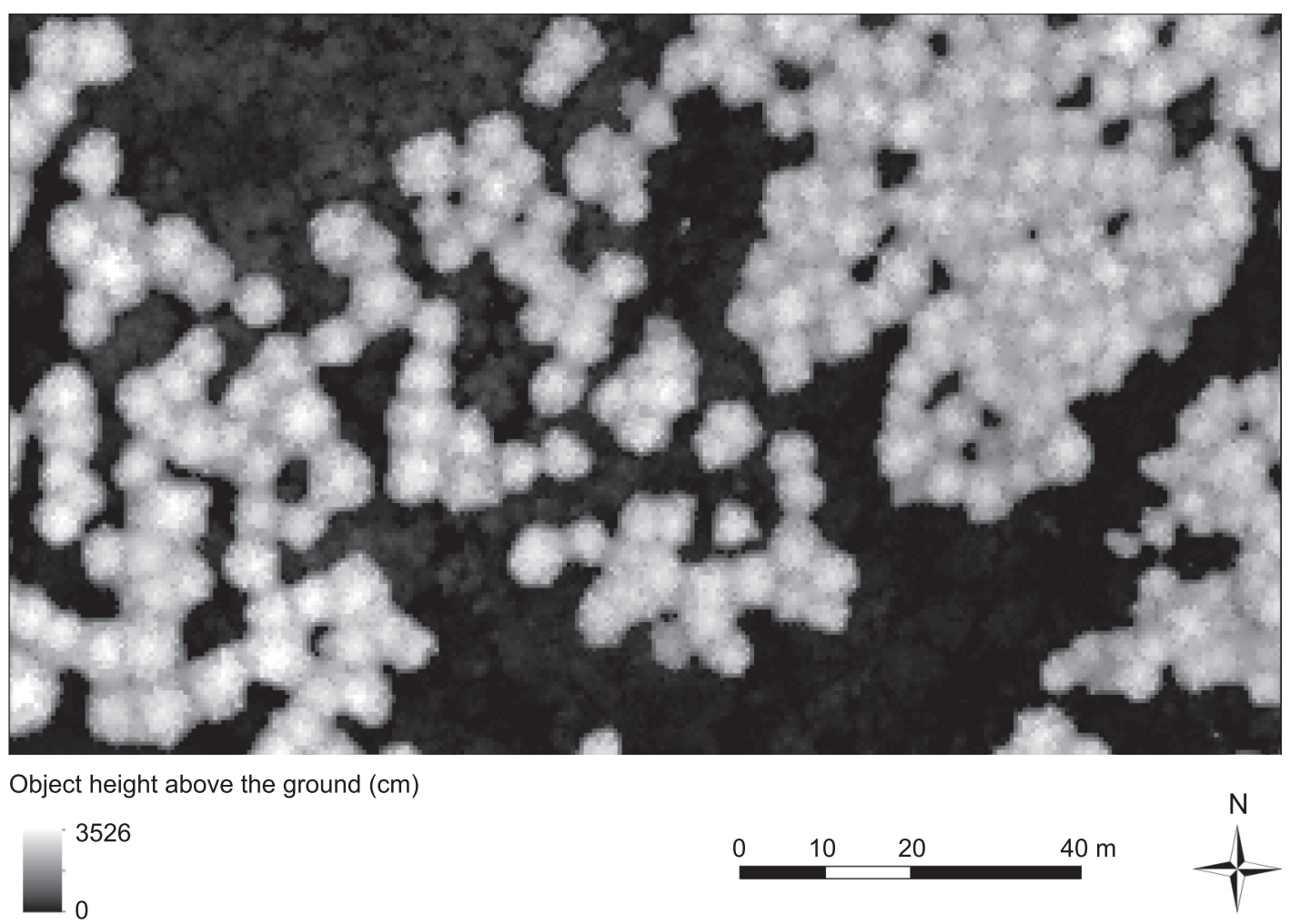

Figure 4. Example of Spruce stand with various stand closures. Pixel values are height of the objects above ground surface. Bright pixels represent height objects.

$0.5 \mathrm{~m}$ pixel leg, it would cause shape generalisation for the youngest trees (1-2 age class) and significant decrease in the number of found trees. Regarding older trees (5-6 age class), it would generate a very detailed shape of the tree crown. As a result of segmentation, it would be possible to obtain few smaller crowns instead of one, bigger. Segmentation of taller trees would usually require earlier shape generalisation. To optimise the process of determining tree number, it is possible to apply smaller pixel size (for instance, $0.25 \mathrm{~m}$ ) for younger age class and larger pixel size for older age class $(1.0 \mathrm{~m})$. Validity and possibility of tree detection in younger age class is a matter of discussion. First, it is very difficult and requires high expenses (buying denser, ipso facto, more expensive data). Secondly, it is not economically justified from the management point of view. Segmentation in older stands gives better results that enable to automate the process and it is economically justified.

\section{Technical factors related to the flight and data acquisition parameters}

The characteristics of the photogrammetric flight along with the density of ALS data expressed in the number of the primary reflections per $1 \mathrm{~m}^{2}$ (point $/ \mathrm{m}^{2}$ ) are one of the most important technical factors. They determine the accurate number of effective signals that return to the receiver. Flight altitude and footprint size influence segmentation accuracy (Hirata 2004; Hyyppä et al. 2005). The accuracy of tree segmentation decreases with increase in the flight level (and in connection to it - the laser footprint size on the ground increase). Difficulties are not significant (up to few percent), however, laser footprint size influences the accuracy of determining crown extant and tree height. Due to the aforementioned fact, laser footprint should be as small as possible (Persson et al. 2002). This improves the accuracy of the analysis and penetration of forest environment. If a beam sent by a scanner reaches an obstacle, it reflects and a coordinate of the obstacle localisation is calculated. Therefore, if the beam is 


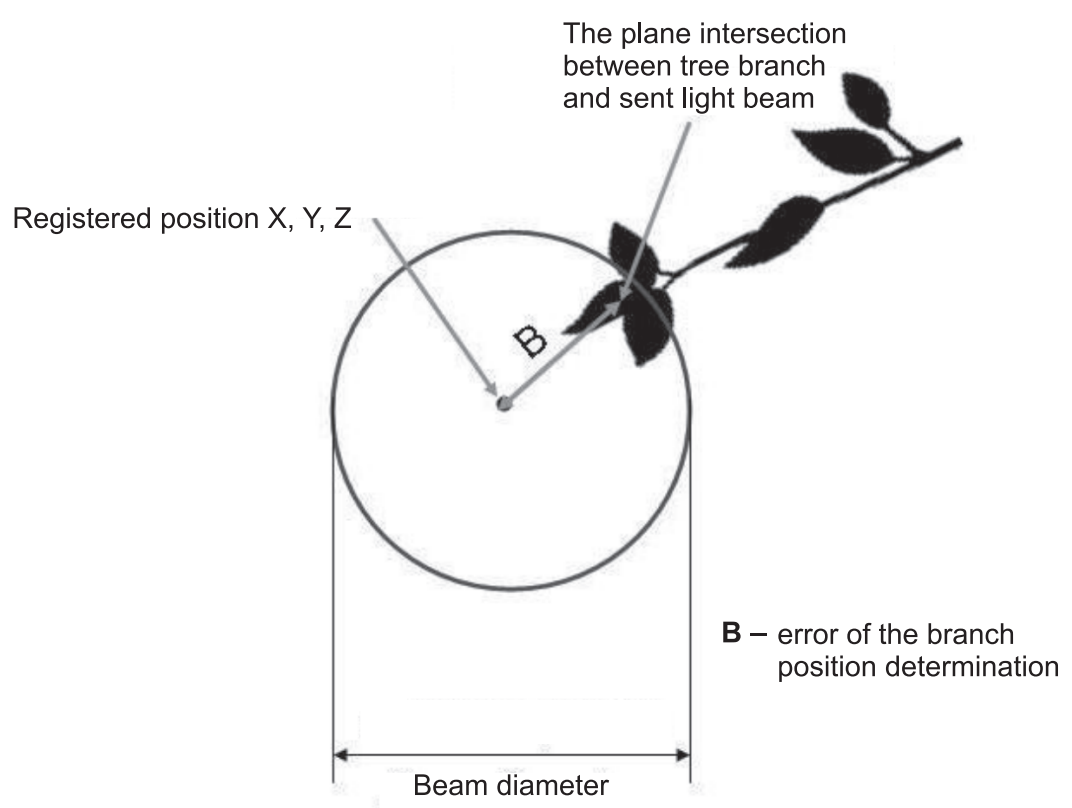

Figure 5. Influence of footprint size and its interaction with object on location terror size, maximal error is equal to half diameter of the footprint

larger, the larger error in determining the locations of forest elements can occur under the assumption that a beam intersects the object with its utmost part (Fig. 5). It is impossible to calculate the error.

The minimal number of primary reflections registered on the selected area is yet another factor that influences tree detection accuracy. The minimal number, which allows for the determination of tree in a credible manner (depending on a stand age and a forest stand composition), reaches 3-5 points $/ \mathrm{m}^{2}$ (Hirata 2004) or 6-10 points per tree crown (Maltamo et al. 2004c). In Scandinavia, the data of about 1 point $/ \mathrm{m}^{2}$ density are used due to lower stand density. The density of ALS data is a condition of obtaining accurate and detailed CHM generated on the basis of the aforementioned data (Hirata 2004). Too low number of points results in a lower resolution model (larger pixel). This, in turn, leads to decreased accuracy in determining tree number (Stereńczak et al. 2008). In addition, density and diameter that laser beams achieve on an object condition the probability of finding the tree top. Additionally, these factors affect the accuracy of tree height measurements.

Point cloud density, obtained from ALS data, depends on the type of LIDAR system and the flight altitude. The type of ALS system influences the spatial pattern of laser beams sent to the ground as well as their frequency (Stereńczak 2010b). If the flight is on the lower altitude and with lower speed, point cloud density is higher, and laser beam diameter on an object is smaller. More dense point cloud enables improving the accuracy of determining tree number.

Regarding technical aspects of flight, scanning angle is the last analysed factor. It influences penetration of forest environment and measurement accuracy. At the footprint of $1 \mathrm{~m}$ and $10^{\circ}$, the error in determining the ground height reaches $+8.5 \mathrm{~cm}$ (Wack, Stelzl 2005). It has been observed that the scanning angle up to $15^{\circ}$ can be used in a very accurate research $( \pm 20 \mathrm{~cm})$ in boreal forest stands (Ahokas et al. 2005). No significant differences were found for the scanning angle $7-15^{\circ}$, with regard to the height number in Digital Terrain Model obtained from ALS data (Morsdorf et al. 2006). The incidence angle should not be larger than $15^{\circ}$ from nadir to obtain the highest accuracy of the analysis. The strip width for such a scan angle would be obviously small and it results in the increase in the expenses of obtaining ALS data. 


\section{Technical factors related to the data processing}

During processing of ALS data, it is possible to mark a large group of factors that influence the process accuracy (Stereńczak 2010b). Processed and delivered, a point cloud can achieve an accuracy of about 10-15 $\mathrm{cm}$. Then data are further processed and analysed. Generating the Digital Terrain Model and the Digital Surface Model are one of the basic processing steps. They can be primary data in many analysis conducted for forestry purposes. The algorithm used to generate Digital Surface Model is another factor, in this case connected with the technical aspects of the data processing, which influences individual tree detection accuracy and tree-characteristic determination accuracy (Fig. 6).

Figure 6 presents the results of applying two different algorithms to generate the digital elevation model. On the left, there is an image where all pixels have height values. On the right side, some pixels are black and have zero value (no data). In the first case (Fig. 6A), the algorithm generates all values of all pixels in the digital elevation model. In the places where ALS data were not registered, pixels values were extrapolated from the nearby pixels (i.e. eight nearby pixels). In the second case (Fig. 6B), algorithm skips pixels where ALS points were not registered. For those pixels, zero values were determined - no ALS data.

The way of processing and preparing the model to segmentation is another factor that has an influence on the obtained data accuracy. Appropriate preparation of the model makes it easier to analyse and increase the accuracy (Maltamo et al. 2004a). Images are quite often filtered to improve the image-processing quality (Nieniewski 2005). Filtering is an important and particular stage of image processing that decides about the segmentation results. It has contextual character. It consists of the determination of pixel value based on the estimation from the nearby pixels within the selected window (Malina, Smiatacz 2005). Filter window is usually square $(3 \times 3,5 \times 5,7 \times 7$, etc. pixels $)$ where for each element of filter matrix, coefficient/ weights were defined. Original image pixel values are multiplied by these coefficients/weights. Increasing the moving window size causes higher generalisation of the analysed image. Figure 7 presents the exemplary Gauss kernel structure.

Low-pass filters are usually used in the process of the tree crown segmentation. They are broadly analysed in digital image analysis literature (Malina, Smiatacz 2005). The following filters are the basic ones: averaging filter, Gauss kernel structure and median filter. Thanks to the filtering step, it is possible to decrease even large differences in height within single-tree crowns. It is also possible to emphasize borders between nearby crowns and the maximum value of the CHM of a single-tree crown CHM pixel size, used for the segmentation, influences tree-number accuracy determination. The larger the pixel is, the smaller the number of accurately delineated trees (Holmgren, Persson 2004; Stereńczak et al. 2008). It is the effect of the CHM generalisation that leads to borders blurring between tree crowns represented in the model (Fig. 8).
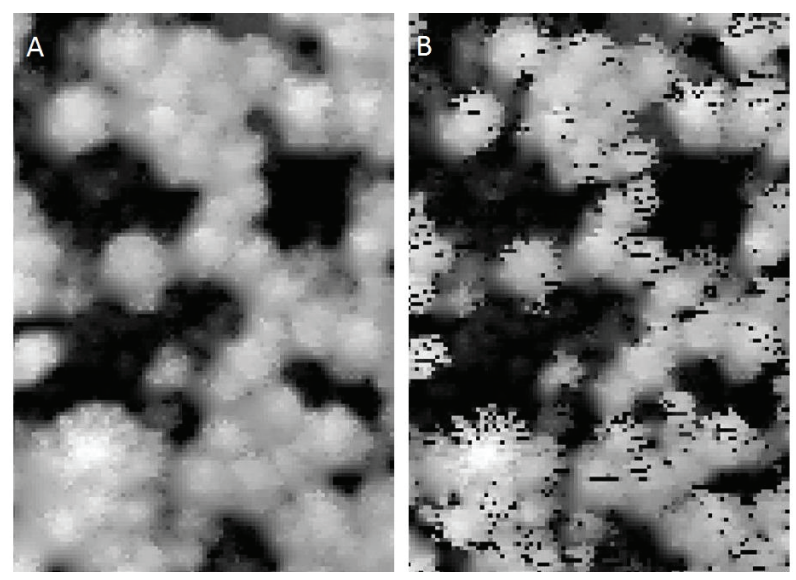

Figure 6. Differences in canopy height models interpolation for the same area, resulted from using different methods of digital surface model interpolation: A - with the height interpolation of all $\mathrm{CHM}$ pixels, $\mathrm{B}$ - without the height interpolation of all $\mathrm{CHM}$ pixels

\begin{tabular}{|c|c|c|c|c|c|}
\hline & 2 & 4 & 5 & 4 & 2 \\
\cline { 2 - 6 } 1 & 4 & 9 & 12 & 9 & 4 \\
\cline { 2 - 6 } 115 & 5 & 12 & 15 & 12 & 5 \\
\cline { 2 - 6 } & 4 & 9 & 12 & 9 & 4 \\
\hline 2 & 4 & 5 & 4 & 2 \\
\hline
\end{tabular}

Figure 7. Typical $5 \times 5$ pixel Gauss kernel structure for $5 \times 5$ pixels window. (Green 2002) 


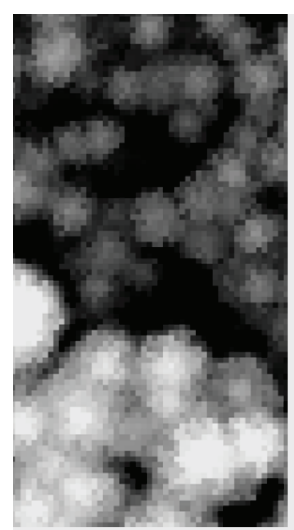

$0,5 \mathrm{~m}$

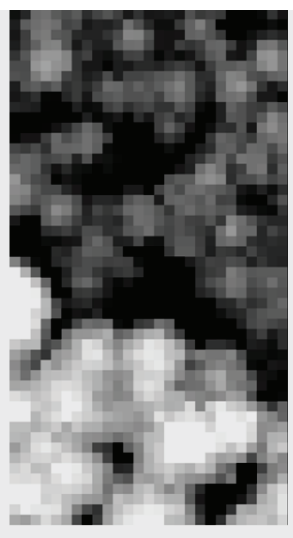

$1 \mathrm{~m}$

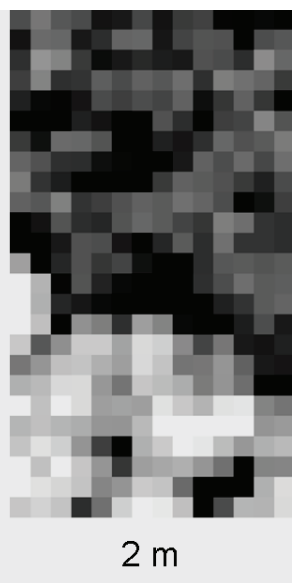

Figure 8. Image pixel size influence on tree crown representation: $0.5 \mathrm{~m}, 1 \mathrm{~m}, 2 \mathrm{~m}-\mathrm{CHM}$ pixel size (m)

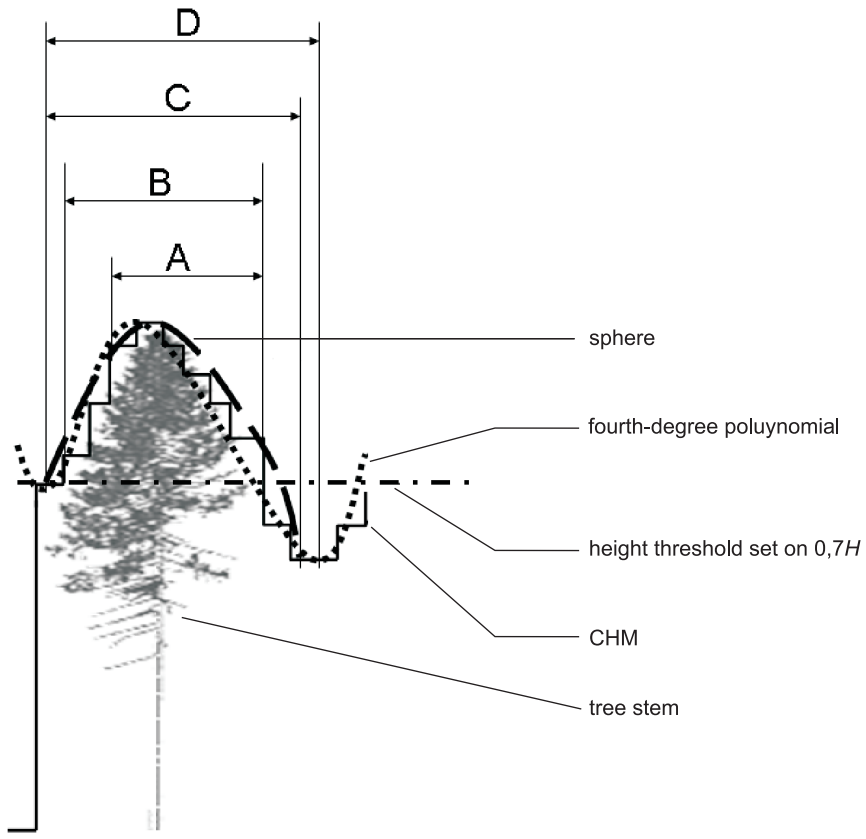

Figure 9. Tree crown extend delineated by using different methods: A - slope of the decrease, B - specified height threshold, $\mathrm{C}$ - fitted sphere, D - fourth-degree polynomial

Increasing pixel size results in smaller crowns being merged with nearby larger crowns (Hyyppä et al. 2005). It can be observed in dense forest stands. The best segmentation results are obtained for the $0.5 \mathrm{~m}$ resolution model (Holmgren, Persson 2004; Heurich, Weinacker 2004; Stereńczak et al. 2008). In comparison to the 0.5 and $0.25 \mathrm{~m}$ resolution models, applying the lower resolution model (for instance, $1 \mathrm{~m}$ ) causes statistically significant decrease in the number of accurately delineated trees (Stereńczak et al. 2008). Adjusting raster to tree-crown size is a general rule that can improve segmentation. However, it is justified only for objects of low crown-size variability.

The way of determining tree crown extent is another significant element of data processing. There are few methods of delineating tree crown extent presented in the literature (Fig. 9). One method uses two cross-sections placed at a right angle. In the next step, fourth-degree 
polynomial is matched to the tree crown shape image represented separately by each section. After delineating the critical point of matched polynomials, tree crown diameter is obtained as the average of measurements done on two profiles (Popescu 2007). There is also another method of determining tree crown extend. It is matching a previously defined sphere to a tree crown image represented in the CHM in the place where the tree top is located (Weinacker et al. 2004). In another method, tree crown extent is defined on the basis of the limit slope value between nearby pixels of the CHM (Diedershagen et al. 2003). It can be expressed by the values of subtraction between the heights or slope value between nearby pixels. When the value of subtraction is exceeded, pixel is not included as an element of the tree crown. The use of the threshold value defined with regard to the maximum tree-height is another method to determine tree crown extent (Stereńczak 2013). Based on this, the height (for instance, $0.7 \times H$ ) below which pixels are not recognised as an element of the tree crown is determined. The method aims at keeping proportions between the highest part of the tree crown represented in the CHM and its actual size (Stereńczak, Miścicki 2012).

\section{The way of tree-detection-results verification}

This section does not characterize crown tree segmentation algorithms. Here the problem of accurate reference data to verify the obtained segmentation results is underline. Different sorts of data can be used in the process. Data can be obtained as a result of:

- ground measurement of tree trunk position,

- ground measurement of tree top position,

- ground measurement of horizontal projection of tree crown extent,

- stereophotogrammetric measurement of tree top in the stereogram of aerial photos,

- stereophotogrammetric measurement of horizontal projection of tree crown extend in the stereogram,

- manual digitalisation of orthophotomaps or the CHM to obtain either tree crowns position or horizontal projection of tree crown extend,

- measurement of terrestrial laser scanning data with and its integration with ALS data.
The aforementioned ground measurements are conducted with the equipment of different qualities. Due to that fact, results are obtained with different accuracies, ranging from centimetres to metres. Similarly, photogrammetric interpretation may pertain to digital images of different pixel sizes, presented in different phonological stages of stands. Using an orthophotomaps or a true-orthophotomap can significantly influence the quality of the obtained data. At the same time, it can also decrease the credibility of data based on orthophotomaps in favour of true orthophotomaps. Moreover, there can be a shift between the time of obtaining ALS data and the time of obtaining reference data, which precludes from reliably analysing the accuracy of algorithm work. All these factors influence data accuracy, which is a reference point for the results of the automatic or semi-automatic forest stand segmentation. I would like to emphasize the fact that scanner is placed on the plane so it analyses from the bird's eye view. Therefore, it is more probable that the reference data obtained from such perspective can be used to better verify the prepared method. Undoubtedly, by verifying the methods of tree-number determination and methods of analysing forest stand (on single-tree tree level), a proper planning of/and obtaining reference data is essential to reliably verify it.

\section{Summary}

The aim of this paper was pointing and characterising different factors, which should be taken into account at preparing a tree detection method and tree features detection by using ALS data. Awareness of the aforementioned factors occurrence and their influence on tree detection results reduces time dedicated to creating new algorithms. Further works are essential to develop tree detection methods, especially in the multilayer forest stands and deciduous stands of compound structure.

\section{Acknowledgements}

This research was conducted due to the Supervisor's Research Grant from the Ministry of Science and Higher Education in Poland: 'Wykorzystanie danych lotniczego skanowania laserowego do określania zagęszczenia drzew w jednopiętrowych drzewostanach sosnowych' (NN309 113237) between 2009 and 2011. 


\section{References}

Ahokas E., Yu X., Oksanen J., Hyyppä J., Kaartienen H., Hyyppä H. 2005. Optimization of the scanning angle for countrywide laser scanning. The International Archives of the Photogrammetry, Remote Sensing and Spatial Information Sciences, 36, 3/W19: 115-119.

Baltsavias E., Wehr A., Lohr U. 1999. Theme Issue on Airborne Laser Scanning. ISPRS Journal of Photogrammetry and Remote Sensing, 54: 61-63.

Będkowski K., Stereńczak K. 2012. Zarys koncepcji quasi-obiektowej metody analizy wielospektralnych zdjęć lotniczych i jej zastosowania do analizy składu gatunkowego drzewostanów [An outline of a quasiobject-based analysis of multispectral aerial images and its use to determine species composition of forest stands]. Roczniki Geomatyki, 10, 5 (55): 19-26.

Będkowski K., Stereńczak K 2013. Sessile oak (Quercus petraea (Mattuschka) Liebl.) trees variability according to an analysis of multispectral images taken from UAV - first results. Ecological Questions (to appear in print).

Clark M. L., Clark D. B., Roberts D. A. 2004. Small-footprint lidar estimation of sub-canopy elevation and tree height in tropical rain forest landscape. Remotes Sensing of Environment, 91: 68-89.

Diedershagen O., Koch B., Weinacker H., Schütt Ch. 2003. Combining LIDAR and GIS Data for the extraction of forest inventory parameters, in: Proceeding of the ScandLaser Scientific Workshop on Airborne Laser Scanning of Forests (eds. J. Hyyppä, E. Næsset, H. Olsson, T. Granqvist Pahlén, H. Reese). Umeå, Sweden, 157-166. ISSN 1401-1204.

Green B. 2002. Canny Edge Detection Tutorial. http://www. pages.drexel.edu/ weg22/can_tut.html, [17.12.2009].

Heurich M., Weinacker H. 2004. Automated tree detection and measurement in temperate forest of central Europe using laser scanning data. The International Archives of the Photogrammetry, Remote Sensing and Spatial Information Sciences, 36, 8/W2: 198-203.

Hirata Y. 2004. The effects of footprint size and sampling density in airborne laser scanning to extracting individual trees in mountainous terrain. The International Archives of the Photogrammetry, Remote Sensing and Spatial Information Sciences, 36, 8/W2, 102-107.

Holmgren J., Persson A. 2004. Identifying species of individual trees using airborne laser scanner. Remote Sensing of Environment, 90: 415-423.

Hyyppä J., Mielonen T., Hyyppä H., Maltamo M., Yu X., Honkovaara E., Kartinen H. 2005. Using individual tree crown approach from forest volume extraction with aerial images and laser point clouds. The International Archives of the Photogrammetry, Remote Sensing and Spatial Information Sciences, 36, 3/W19, 144-149.

Hyyppä J., Yu X., Hyyppä H., Maltamo M. 2006. Methods of airborne laser scanning for forest information extraction, in: 3-D Remote Sensing in Forestry (eds. T. Koukal, W. Schneider). Feb 14-15, 2006, Vienna, Austria, 74-89.

Kaartinen H., Hyyppä J. 2008. Tree Extraction - final report. EuroSDR/ISPRS Commission II Project, 53.

Koch B., Heyder U., Weinecker H. 2006. Detection of Individual Tree Crowns in Airborne Lidar Data. Photogrammetric Engineering and Remote Sensing, 72 (4): 357-363.

Korpela I., Dahlin B., Schäfer H., Bruun E., Haapaniemi F., Honkasalo J et al. 2007. Single-tree forest inwentory using LIDAR and aerial images for 3D treetop positioning, species recognition, height and crown width estimation. The International Archives of the Photogrammetry, Remote Sensing and Spatial Information Sciences, 36, 3/W52: 227-233.

Malina W., Smiatacz M. 2005. Cyfrowe przetwarzanie obrazów. Warszawa, Akademicka Oficyna Wydawnicza EXIT. ISBN 978-83-60434-54-3.

Maltamo M., Eerikäinen K., Pitkänen J., Hyyppä J. Vehmas M. 2004a. Estimation of timber volume and stem density based on scanning laser altimetry and expected tree size distribution functions. Remote Sensing of Environment, 90: 319-330.

Maltamo M., Mustonen K., Hyyppä J., Pitkanen J., Yu.X 2004b. The accuracy of estimating individual tree variables with airborne laser scanning in boreal nature reserve. Canadian Journal of Forest Research, 34: 1791-1801.

Maltamo M., Packalén P., Yu X., Eerikäinen K., Hyyppä J., Pitkänen J. 2004c. Identifying and quantifying heterogeneous boreal forest structures using laser scanner data. International Archives of Photogrammetry, Remote Sensing and Spatial Information Sciences, 36, 8/W2: 153-156.

Miścicki S., Stereńczak K., 2012. Cechy uzyskiwane z przetworzeń wysokościowego modelu koron wykorzystywane w dwufazowej metodzie inwentaryzacji zapasu [Using characteristics based on crown height model in double sampling method of forest stock inventory]. Roczniki Geomatyki, 10, 5(55): 47-54.

Morsdorf F., Frey O., Meier E., Itten K. I., Allgower B. 2006. Assessment on the influence of flying height and scan angle on biophysical vegetation products derived from airborne laser scanning, in: Workshop on 3D Remote Sensing in Forestry (eds. T. Koukal, W. Schneider). Feb 14-15, 2006, Vienna, Austria, 156-161. 
Myszkowski M., Ksepko M., Gajko K. 2009. Detekcja liczby drzew na podstawie danych lotniczego skanowania laserowego [Tree number detection based on airborne laser scanning data]. Archiwum Instytutu Inżynierii Ladowej, 6: 63-72 .

Nelson R., Krabill W., Maclean G. 1984. Determining forest canopy characteristics using airborne laser data. Remote Sensing of Environment, 15: 201-212.

Nieniewski M. 2005. Segmentacja obrazów cyfrowych. Metody segmentacji wododziałowej. Warszawa, Akademicka Oficyna Wydawnicza EXIT. ISBN 8387674-82-6.

Persson A., Holmgren J., Soderman U. 2002. Detecting and measuring individual trees using airborne laser scanning. Photogrammetric Engineering and Remote Sensing, 68(9): 925-932.

Persson A., Holmgren J., Söderman U. 2003. Detection, measurements, and species classification of individual trees for forest inventory and visualization, in: Proceeding of the ScandLaser Scientific Workshop on Airborne Laser Scanning of Forests (eds. J. Hyyppä, E. Næsset, H. Olsson, T. Granqvist Pahlén, H. Reese). Umeå, Sweden, 223-234. ISSN 1401-1204.

Popescu S. C. 2007. Estimating biomass of individual pine trees using airborne LIDAR. Biomass and Bioenergy, 31(9): 646-655.

Sołoduchin W. I., Kulasow A. G., Utenkow B. I., Żukow A. J., Mażugin I. N., Emalanow W. P., Kopolow I. A. 1977. Sjomka profila krony dieriewa s pomoszczju laziernego dalnomiera. Lesnoje Choziajstwo, 2: 71-73.

Stereńczak K., Będkowski K., Weinacker H. 2008. Accuracy of crown segmentation and estimation of selected trees and forest stand parameters in order to resolution of used DSM and nDSM models generated from dense small footprint LIDAR data. The International Archives of the Photogrammetry, Remote Sensing and Spatial Information Sciences, 38, B6b: 27-33.

Stereńczak K. 2010a Wykorzystanie danych lotniczego skanowania laserowego do określania zagęszczenia drzew w jednopiętrowych drzewostanach sosnowych. Praca doktorska. Wydział Leśny, Szkoła Główna Gospodarstwa Wiejskiego w Warszawie.

Stereńczak K. 2010b. Technologia lotniczego skanowania laserowego jako źródło danych w półautomatycznej inwentaryzacji lasu [Airborne Laser Scanner technology as a source of data for semi-automatic forest inventory]. Sylwan, 154 (2): 88-99.
Stereńczak K., Miścicki S. 2012. Crown delineation influence on standing volume calculations in protected area. The International Archives of the Photogrammetry, Remote Sensing and Spatial Information Sciences, 39, B8: 441445.

Stereńczak K. 2013. Określenie zagęszczenia drzewostanów sosnowych i mieszanych $\mathrm{z}$ wykorzystaniem danych $\mathrm{z}$ lotniczego skanowania laserowego (to appear in print). Sylwan, 157 (8): 607-617.

St-Onge B., Jumelet J., Cobello M., Vega C. 2005. Measuring individual tree height using a combination of stereophotogrammetry and LIDAR. Canadian Journal of Forest Research, 34: 2122-2130.

Tiede D., Blaschke T., Heurich M. 2004. Object-based semiautomatic mapping of forest stands with laser scanner and multi-spectral data. The International Archives of the Photogrammetry, Remote Sensing and Spatial Information Sciences, 36, 8/W2: 328-333.

Tiede D., Hochleitner G., Blaschke T. 2005. A full GIS-based workflow for tree identification and tree crown delineation using laser scanning. ISPRS Workshop CMRT 05. 2930.08.2005. Vienna, Austria.

Tompalski P., Wężyk P., de Kok R., Kukawski M., 2009. Determining tree number in pine stands using airborne laser scanning data and orthophotos. Annals of Geomatics, 2(32): 133-141.

Vauhkonen J., Ene L., Gupta S., Heinzel J., Holmgren J., Pitkanen J. at al. 2010. Comparative testing of single-tree detection algorithms. Freiburg, Niemcy. Proceedings of SilviLaser.

Wack R., Stelzl H. 2005. Laser DTM generation for SouthTyrol and 3D - visualization. ISPRS WG III/3, III/4, V/3 Workshop "Laser scanning 2005", Enschede, the Netherlands, September 12-14, 2005, 48-53.

Weinacker H., Koch B., Heyder U., Weinacker R. 2004. Development of filtering, segmentation and modeling modules for LIDAR and multispectral data as a fundament of an automatic forest inventory system. The International Archives of the Photogrammetry, Remote Sensing and Spatial Information Sciences, 36, 8/W2, 50-55.

Wężyk P., Tompalski P., de Kok R., Szostak M., Kukawski M. 2010. Metoda określania liczby drzew w drzewostanie z wykorzystaniem danych ALS oraz ortoobrazów [Method of the tree number estimation in the pine stand using ALS data and true orthoimages]. Sylwan, 154 (11): 773-782.

Translated by: Martyna Olszowska. 